\title{
From Chinatown to Gunga Din Highway: Notes on Frank Chin's Writing Strategy
}

\section{E. San Juan, Jr.}

Exploring Frank Chin's work, particularly in his latest novel Gunga Din Highway, the essay endeavors to re-situate ethnic writing in the historical specificity of its inscription in the United States as a racial polity. This cognitive remapping of the literary field as reconfigured by multiculturalist liberalism may be accomplished by examining Chin's cultural politics. Chin's mode of strategic writing interrogates the modelminority myth and the premises of cultural nationalism. While it rejects the pluralist resolution of the traditional conflicts in the Chinese diaspora, Chin's satiric impulse proposes a defamiliarization of Asian American "common sense" adequate to provoke a revaluation of the presumed conjunction of ethnicities, cultures, and nationalities in the current counter-terrorist milieu.

The "myth of Asia" and its ramification in what Edward Said calls the discourse of "Orientalism" (1978), once a serious obstacle to rigorous scientific analysis of disparate societies, no longer dominates with its obscurantist mystique. The comparatist scholar John Steadman exposed some time ago the 


\section{Ethnic Studies Review Volume 24}

duplicitous equivocality of notions about Asia, or Eastern cultures, as a symptom of Western/European anxieties and malaise (1969). But a more recalcitrant and perhaps more insidious pathology has taken its place: reification of cultures. Arif Dirlik (2001) recently called attention to the way in which the assimilationist category of "Asian America" (which homogenizes the heterogeneous ethnicities subsumed within it: Filipino, Chinese, Japanese, Korean, Vietnamese, and so on) erased crucial geographical, historical and social differences. As a reaction the privatized and particularistic separatism of identity politics dissolved the historical specificity of cultural practices, leading to the fabrication of abstract essentializing identities like "Chineseness"-a return of Orientalism in an age of multiculturalism and the cult of ethnic differences. How do we move beyond such paralyzing binarisms and metaphysical dualisms? As a heuristic exploration, I attempt to sketch here one way of moving beyond the perils of racializing culturalism by examining the fraught interface between imagination and society in the cultural politics of one controversial Chinese American artist, Frank Chin.

Caught in the unflagging "culture wars" of the last three decades, any inquiry into the status of a region of creative expression as Asian American, more specifically here Chinese American, writing is fraught with all the old issues over the relation of art to the political and social formation which it inhabits. We need to situate the aesthetic or literary object in what Pierre Bourdieu calls "the field of power" (1995). For the dominant liberal consensus, literature occupies a transcendent space free from prior moral or ideological commitments, hence readers can enjoy Amy Tan and Maxine Hong Kingston on the same level as they would Gertrude Stein or Katherine Anne Porter. Since the sixties, however, the consensus has allowed for the reconfiguration of "minority" or ethnic writing in the new category of multicultural literature of the United States, according them "equal and separate" position.

This gesture of tolerance is both compromising and complicitous. It patronizes the exoticized cultural product even while it claims to judge it in terms of universalistic criteria. One may ask: Is Amy Tan's The Joy Luck Club, inserted into the diversity curriculum, now to be celebrated as an integral part of 
American literature? That question is more contentious if trivial than the one of whether Maxine Hong Kingston, now canonized as a major American writer, is perfectly assimilated so as to erase the ethnic patina and render her safe for general, not just elite, consumption. Has the original "Chinese" aura produced by reviews and public opinion of her novels been subsumed into the pluralist hegemony of multicultural America to make her representative? Clearly the question of nationality, of identifying with a nation or citizenship granted by the nationstate, becomes crucial when we (I from the Philippine perspective; my colleagues from Hong Kong, Taiwan, and elsewhere, from another) view a concrete literary formation in the context of specific times, places, and interrelations among them. Clearly neoliberal multiculturalism is neither neutral and impartial nor disinterested in the Kantian sense.

Before I shift the focus from the general to the particular, I want to underscore the fact that the antagonism between the aestheticist and the socially committed stance persists among the litterateurs of Asian America. It functions as a microcosm of the stratified and hierarchized field of power. Consider, for example, the opinions expressed by Garrett Hongo on Cynthia Kadohata and Pulitzer-winner Robert Butler. Hongo chides Asian Americans for being "immature" because they are "so unused to seeing cultural representations of itself" so that they criticize Kadohata for not mentioning the internment camps in her novel The Floating World. Hongo praises Butler for creating "commonality" in his stories of Vietnamese refugees, for his "humanistic politics" and "powerful artistry." Hongo then blames the confusion of

general thought in American culture (as enacted by media and the ephemeral communal mind) [which] tends to oversimplify complex social and artistic issues, with the habitual comminglings and false oppositions of matters of art with matters of social justice. The problem, ultimately, has to do with confusing and, finally, conflating the two realms $(1998,55)$.

Although Hongo evinces awareness of the dangers of "minstrelsy by the white culture ventriloquizing the ethnic experience and colonizing the mind of the Other for the purpose of reinforcing cultural dominance" (1998, 53-54), he is curiously 
naive in accepting the contrived separation between art and society, humanism and racism, that generated in the first place the confusions he himself suffers from. The symptoms of extreme alienation, instanced for example by the fragmentation of human activity and schizoid behavior found in late capitalist society cannot be diagnosed without grasping the larger history of the socio-political formation of the United States as a complex overdetermined totality of social relations. Racism, the underlying cause of the "culture wars" between a white supremacist order and the subordinated peoples of color, cannot be grasped fully and resolved without the transforming the material historical conditions that make it possible. What is imperative is a critical review of the racial/class hierarchy that constitutes the social order of the United States, its historical construction as a hegemonic articulation of classes, races, nationalities, sexualities, together with the manifold contradictions that define the parameters for change.

We need to confront the historical reality of the United States as a "racial polity" founded on conquest, slavery, and genocide (Mills 1997). On the specific question of where Chinese Americans are positioned in the historical development of this racial polity and where its cultural modalities can be inscribed, a preliminary response can be sampled in a study by Ling Chi Wang that raises more questions than it answers. Wang is critical of two paradigms: the assimilationist one based on the melting-pot myth which subsists on the ideology of white supremacy and the loyalty paradigm. The latter involves the emphasis on preserving a Chinese cultural identity which entails some kind of political/ economic loyalty of "overseas Chinese," the "sole obsession" of both government policies and scholarly inquiries by both governments in Taiwan and mainland China.

Wang rightly criticizes both paradigms deployed in scholarly studies of Chinese in the United States as simplistic, biased, and totally inadequate. Aside from assuming Chinese America to be homogeneous and monolithic, the two frameworks "exclude the perspectives, interests, rights, and well being of the Chinese American community." Abstracting from the empirical record, Wang points to three crucial factors that define the Chinese diaspora in the U.S.: 1) the resistance 
against racial oppression and extraterritorial domination; (2) the impact of U.S.-China relations on the formation and development of Chinese America; and (3) the segmentation and conflict within the community by class, gender, and nativity over time and the sentiment, perspective, and voice of each segment $(1995,158)$.

By a simple inversion, Wang proposes an alternative paradigm that would reconceptualize assimilation and loyalty, substituting for assimilation the concept of racial exclusion or oppression, and for loyalty to the homeland the notion of extraterritorial domination. These two trends-racial exclusion and extraterritorial domination-then "converge and interact in the Chinese American community, establishing a permanent structure of dual domination and creating its own internal dynamics and unique institutions" $(1995,159)$.

From an evolutionary perspective the opposites need to be reconciled. After reviewing the historical vicissitudes of these two trends, Wang concludes that

lliberation from the structure of dual domination is therefore the goal for the emergence of a new Chinese America in the multiracial democracy of the U.S. envisioned by the Chinese Americans involved in the civil rights movement of the late 1960s and early 1970s $(1995,165)$.

How that emancipatory goal is to be achieved remains unclear.

The invocation of a "multiracial democracy" without altering property/power relations is highly suspect. Notwithstanding this reservation, I think Wang has insightfully summarized the political genealogy of Chinese America-the ideological foundation of exclusion in contract labor, the presumed non-assimilability of the Chinese, the conservative and reactionary local institutions and practices that permitted the intervention from the governments in Taiwan and mainland China, and lately the transnational movements of information, capital, and people in global capitalism. What is starkly missing is any analysis of how precisely the ideological and cultural apparatuses of the hegemonic order-no radical change is suggested for this-continue to reproduce the assimilationist paradigm as well as reinforce the loyalty compulsion. In fact Wang notes the influence of the cultures and lifetyles of China, Taiwan, and Hong Kong 
on the already segmented Chinese American community. More important, the underlying schema for change is not the racial polity but a self-equilibrating liberal market-centered system.

\section{Unravelling Apartheid?}

No doubt times have changed. Chinese Americans are praised by arch-conservative Linda Chavez as superformers in climbing the ladder of social and economic mobility, serving as protowhites placed between African Americans and the EuroAmerican majority. Peter Gran describes the "buffer race" strategy for preserving the status quo:

The state through its immigration policy inserted one or more groups, the buffers, into society between black and whites to conflict with the interests of both, thereby deflecting the focus on race off the blackwhite issue, diffusing it into what is now called multiculturalism (1996, 347).

This ineluctably complicates the race/class/gender dialectic. The mutations in social relations of reproduction that accompany the change from finance capitalism at the turn of the century to the Depression, the Cold War, and the new globalization schemes of the industrialized states are elided by a narrow focus on bureaucratic, regulatory adjustments. The absence of a dialectical construal between the logic of capital and the hegemonic process vitiates the critique of assimilationism and intervention from outside through local agencies. Taking account of transnationality or transmigrancy will not challenge capital's corporate monopoly of power over the processes of immigration, job discrimination, residential segregation, and other institutional mechanisms of the regulatory, monopolistic state.

Empiricism vitiates any simple tabulation of factors surrounding racism and extraterritorial intervention. Starkly absent from Wang's historical summary is the evolution of the older stereotype of Fu Manchu or "heathen Chinee" as evil incarnate to the model minority exemplar in tandem with the rise of neoconservative Asian American "middlemen" as key players in the political scene. Connie Chung and Wen Ho Lee cannot so easily be yoked together without ideological violence. Neil Gotanda takes note of this dramatic transformation of the 
Asian American "yellow horde" into overachievers, an intermediate racial category or "racial buffer" between whites and a burgeoning "underclass." Add to this the phenomenon of what Peter Kwong calls the "new Chinatown" whose underground economy of "internal colonialism" outside the mainstream U.S. economy and labor market escapes Wang's dual paradigm and its alternative.

We should factor in the conjuncture of the fin de siecle pettybourgeois anarchism and the neoliberal agenda for universalizing "free trade" and privatization everywhere. In the wake of the 1992 Los Angeles uprising, Glenn Omatsu (1994) describes the emergence of Asian neoconservatives in California, exploding the panethnic racialization of the sixties with the resurgent class antagonisms of a declining industrial economy. After September 11, 2001, the war against terrorism may have disrupted the academic syndrome of reducing "race" to ethnicity. By virulent racial profiling the coercive agencies of the state have counter-fetishized the physiognomy of the Arab, resulting in the systematic surveillance, harassment, and even murder of Arab Americans, citizens of Middle Eastern origin, South Asians and other dark-skinned immigrants.

Let us assume, however, the persistence of a gradualist trend. In retrospect, it is perfectly conceivable to posit that freedom from the dual tyranny of racial exclusion and extraterritorial domination can take the form of a pluralist/multicultural ethos and an ethnocentric politics of identity. Despite its challenge to orthodoxy, both Tan's oeuvre (from The Joy Luck Club to The Thousand Secret Senses) as well as the more sophisticated inventions of David Hwang, Fae Mae Ng, Shawn Wong, Wing Tek Lum, Marilyn Chin, and others, can and have been appropriated for disempowering their agents and entrenching a "separate but equal" prophylactic compromise. Chang-rae Lee's Native Speaker signals a self-reflexive turn that disturbs the lift-one's-bootstraps complacency.

Kingston herself is now a sacred icon of pluralist feminism-a success story for nativist as well as overseas, diasporic Chinese. Civil rights demands for some pettybourgeois elements have been fulfilled by the fetishism of hybridity and heterogeneity, making the hyphen the erotic marker of a privileged difference. If the margin has moved to the center 


\section{Ethnic Studies Review Volume 24}

or has been accommodated to the core by a strategy of cooptation and displacement, the racial polity is preserved and strengthened in its political-economic functionality and ideological effects. Postmodernist discourse and criticism, eulogizing boutique multiculturalism above the political economy of maintaining consensus, runs rampant in the service of a pluralist metaphysics of the free market and individual freedom via consumerism (San Juan 1998, 1999). Institutional racism thrives on individualist honors.

One way of exploring how to seize the "weak link" in the U.S. sociopolitical formation is to pursue a historical-materialist critique of the contradictions that underlie the structures of the racial order. I want to use Frank Chin's writings as allegories of Chinese American historical specificity. In "Revisiting an 'Internal Colony': U.S. Asian Cultural Formations and the Metamorphosis of Ethnic Discourse," a chapter in my book Beyond Postcolonial Theory, I alluded to Chin's attempt to dismantle the bipolarizing logic of the hyphenated sensibility found in Jade Snow Wong and other pre-World War II writers and to project instead a heroic myth of the Chinese workers who built the railroads, excavated tunnels, cleared the wilderness of Hawaii, and made enormous sacrifices to lay the infrastructure for industrial capitalist America. I alluded to how Chin has been able to neutralize the humanist, neoliberal reconstitution of the self with a "postmodern pastiche that may be an astute maneuver to undermine commodity fetishism" (1998, 189). "Commodity fetishism" is my shorthand term for the whole regime of alienation, more exactly reification (as defined by Lukacs [1971] and Goldmann [1975] ), that distinguishes everyday life in a society centered on exchange-value, on the operations of the market.

Reification in a racial polity manifests itself as racial inferiorization, exclusion, marginalization, and subordination of peoples marked as Others/aliens as a mode of constituting a majoritarian identity, articulated with class, sexuality, gender, and nationality. Reification in the cultural field today expresses itself as the valorization of difference to compensate for the damages inflicted by a homogenizing Eurocentric pseudo-universalism. What David Harvey calls the "Leibnizian conceit" (69), in which a monadic subjectivity internalizes the world and 
its totality of relations, was displayed earlier in Hongo's bifurcation of aesthetics and politics as two separate realms. This conceit also legitimizes the idea of the artist as demiurgic force so prevalent in postmodernist apologetics. Deploying satiric humor, parody, and carnivalesque tropes, Chin suceeds in destroying the Leibnizian conceit. By emphasizing historical specificity and the sociopolitical constitution of the mode of literary production Chin subverts commodity aestheticism. Deploying a distancing slyness reminiscent of Brecht (see Jameson 1998), Chin refunctions his own life-history as a means of carrying out a painstaking demystification of the paradigm of assimilation.

\section{Articulating Class, Race, and Nationality}

Racial dynamics cannot be divorced from how categories of class and nationality operate in U.S. society. In a contribution to Studs Terkel's volume, Race (1992), Chin explores the embeddedness of the Chinese habitus in American life and its indivisibility from the class/race/nationality parameters of subordination. He states that from his childhood he has been "trying to find out exactly what" he is, "an American of Chinese descent." This formulation is multiaccented, contingent on historical conjuncture and context. I should like to emphasize that Chin's writing strategy is not a quest for an essential quality or attribute of "Chineseness" but a cognitive and pragmatic mapping of the terrain of a racialized formation. Sucheng Chan (1991), King-kok Cheung (1990), and others condemn Chin's "machismo" and his alleged claim to be the only "authentic" Asian American writer. There is some basis for this, but it does not appreciate the larger project of a disarticulation of the hegemonic order and re-interpellation of the racialized, subjugated subject.

Unlike Asian postmodernists, Chin strives for a synthesizing appraisal of the social totality. Chin's mode of calculating how the "ethnic" negotiates the American scene implies a crtique of liberal pluralism as well as the essentialist assumptions of civic republicanism:

Oakland is the Tower of Babel. All these languages. And nobody even speaks English like everybody else. l've come to believe that monotheism encourages 
racism, whoever practices it. There is only one God and everyone else is an infidel, a pagan, or a goy. The Chinese look on all behavior as tactics and strategy. It's like war. You have to know the terrain. You don't destroy the terrain, you deal with it. We get along, not because we share a belief in God or Original Sin or a social contract, but because we make little deals and alliances with each other (Terkel 1992, 310).

Chin points out that because he was raised by white folks during World War II, he was saved from ideas of Chinese inferiority, of parents having proprietary rights over children, from the seductions of yellow minstrelsy. The powerful influence of the black radical movement in the sixties-dramatized in satiric and elegiac ways in The Chickencoop Chinaman and The Year of the Dragon-is mediated in the typifying gestus of the Chinatown Red Guards who violently command Chin to "Identify with China!"-the California Maoists beat him up and accuse him of being a "cultural nationalist." David Palumbo-Liu comments that Chin and the Red Guards fail to see that both terms in "Asian America" signify "a psychic rationalization, and that the problem of cultural nationalism involves "the historical materiality of a culture produced in a psychic space wherein a particular and contingent formation of the nation appears in relation to multiple identifications which are themselves driven by specific contingencies" (1999, 308).

Chin's "America," is, however, less a cover for cultural nationalism than a ruse for exposing hegemonic truisms. As a teacher Chin was attacking racism in its overt forms, a racial ostracism that reduced Chinese Americans to "an enclave, like Americans working for Aramco in Saudi Arabia. Chinatown may be a stronghold of Chinese culture, but we're Chinese Americans" (312). He denounces the practices that have converted the Chinese Americans into "a race of Helen Kellers, mute, blind and deaf," the perfect minority worshipping Pearl Buck and embracing Charlie Chan, "an image of racist love," as "a strategy for white acceptance" (313). Chin takes account of how social peace via individual/group competition is preserved by the inculcation of prejudice throughout the population. He recalls how David Hilliard of the Black Panthers got up in Portsmouth Square and said: "You Chinese are the Uncle 
Toms of the colored poples" ( Terkel 1992, 314). Chin finds this apt, but Chinese youth imitating black populism is not the solution. Nor is the temporary strategic ruse of using English "as a matter of necessity" in a white man's world, which he observes among the Indochinese immigrants whom he describes as "the unredeemed Chinese Chinese."

A kind of peasant cunning using the "weapons of the weak" characterizes Chin's bravado, his predilection for exhibitionist belligerence. This has earned him sharp rebuke from self-avowed gatekeepers of Asian American culture and assorted orthodox moralists. Chin's method is not a matter of reversing discourse but a retrieval of a submerged tradition: the practical materialism of the Chinese plebeian grassroots, the proletariat in city and countryside (Needham 1975). To interrogate self-contempt as a tactic of survival and legitimize a Chinese American sensibility in his works, Chin is often quoted as adopting a heroic martial posture and outlook based on his application of Sun Tzu's Art of War and the Chinese cultural tradition embodied in the classic texts of Three Kingdoms, The War Margin, and Monkey's Journey to the West. Some commentators also impute to Chin the role of reconstructing the Chinese tradition in the way of Caliban and Kwan Kung (Leiwei Li 1991). But Chin, I think, is not interested in postcolonial mimicry or a recovery of a putative Chinese American tradition. In his essay, "Our Life is War," Chin argues that "What is of supreme importance in war is to attack the enemy's strategy" $(1983,28)$, hence the importance of surveying the terrain or context of the struggle, analyzing the contradictory trends immanent in the forces engaged, and seizing the "weak link" to resolve the contradictions by stages and enable a release of human potential for future projects of liberation.

As a propaedeutic guide, I would like to delineate Chin's dialectical mode of problematizing with reference to his latest work, Gunga Din Highway. The novel is an elaborate neopicaresque staging of a pretext for an understated satire of American highbrow and mass culture, rehearsing the familiar repertoire of racist cliches, stereotypes, icons, and folkloric doxa of mainstream culture. It is organized around the conflict of generations, specifically between Longman Kwan, the father of Ulysses, who aspires to be the first Chinese to play Charlie 
Chan after having had a career of playing Chan's Number Four Son and as "the Chinaman who dies." Ulysses, the third son of a father produced by incest, revolts against the patriarch who urges him to take on "the image of the perfect Chinese American to lead the yellows to build the road to acceptance towards assimilation" $(1994,13)$. Which road will the prodigal son take?

The conventional parodic form modernized by Chin leads to an inversion if not abortion of a young artist's development found in the traditional education novel. Ulysses and his friends, Diego Chang and Benedict Han, are instructed by their Chinese schoolteacher to "master all the knowledge of heaven and earth...so as to see the difference between the real and the fake." They outwit their teacher. They anticipate the precept that good judgment springs from a hermeneutics of suspicion. The last chapter of the novel renders the success of Ulysses in refusing the legacy/inheritance of Charlie Chan, a synecdoche for the systematic Americanization of the Chinese, even though at the end he accepts being a figurehead for the extended family. The father's prestige is vindicated as he is described in a fictional movie, Anna May Wong, an airplane movie with an allChinese bomber crew, in which the father departs from the Chan syndrome/Gunga Din Road and enjoys a symbolic resurrection and rehabilitation. The lesson seems to be that the past is always redeemed in moments of danger, of crisis, when we seize opportunities for transformative action. "Life is war.... Let the good times roll!" Diego Chang intones. If life is war and revolution, then Ulysses wins it when he refuses all the normative expectations of the dominant society. Contrany to modernist decorum, the section "Anna May Wong" and its take-off sequence splice the father's death with the joyous drive toward birth, a delivery and deliverance at the same time. The trope of flight, passage, transition, etc. unfixes the dual reflex of assimilation/loyalty discussed earlier.

Consanguinity or blood lineage counterpoints breaks by migration, alienation, and betrayal. The public sphere cannot be separated from the private realm. Still, we cannot evade the thematic burden of identity, whether filial, collective, private, decentered or intertextual. What are the conditions of its possibility? And is this task of identification meaningful for a novel 
that with its critical and deconstructive thrust undermines the quest for origins, essences, authenticity, destinies, transcendent and/or primordial forms? Chin pokes fun at the notion of a singular isolated tradition: "If Charlie Chan uses first-person pronouns, does not walk in the fetal position, is not played by a white man, and looks and acts like a real Chinese, he's not Charlie Chan anymore" (1994, 355). This suggests that identification is always dialogic in Bakhtin's (1981) sense, or better yet, heteroglossic and intertextual in that the critique of hegemony always takes mass prejudices as the point of departure for their subversion.

The form of Gunga Din Highway, at first glance, seeks to reconcile the disintegration of the traditional world with the artist's desire for wholeness of understanding. As we shall see, the attempt executed partly through an attempted mimesis of Joyce and Homer only heightens the contradictions and, at best, instigates us to react to the crisis of the old order. Broadly surveyed, the four parts of the novel unfold the history of the Chinese in the United States in the adventures of Ulysses Kwan, the descendant of the god of fighters and writers, and variants of his character. Before "Home" can be reached, the protagonists have to experience a protracted agon from "Creation" to "The World" and "the Underworld."

One can discern a chronological progression from the Mother Lode country of California in World War II to San Francisco coffeeshops in the fifties, passing through a Seattle rock-flamenco-blues festival and the activities of radical groups in the sixties to off-Broadway and the orientalist version of Pandora's box in the seventies, to middle-age capers in the eighties, and finally to the disclosure of family secrets in the nineties. In Chins genealogy, the hero is basically the anti-hero, a subversion of identity politics by a cosmic metanarrative and a carnivalesque collage of episodes without much logical causality. The rationale is provided by his reading of Chinese mythology:

The world, the giant, and the Mother of Humanity create a world where every hero is an orphan, a failed scholar, an outlaw, an outcast, an exile on the road of life through danger, ignorance, deception, and enlightenment" (1994, vii). 


\section{Ethnic Studies Review Volume 24}

The education of Ulysses attains a climactic point in his encounter with the Horse, their Chinese teacher, at a historic juncture when the United States is fighting a war in Korea while the French just have suffered defeat at Dien Bien Phu in colonial IndoChina. The Horse's teaching sketches the secular, open-ended triangulation of Ulysses' emergent identity:

'I can teach you to read and write Chinese,' the Horse said, 'but you will never be Chinese. And by now you should all know no matter how well you speak English and how many of the great books of western civilization you memorize, you will never be bokgwai, white European Americans. The Chinese kick you around for not being Chinese. And the whites kick you around for not being American. Obviously you are neither white nor Chinese, but you tell me what does that mean? What is it? You are the stone monkey come to life. To learn the difference between stone idea and living flesh and blood, you must learn everything Chinese and American there is to know, you must master all the knowledge of heaven and earth, become The Sage equal to The Emperor of Heaven so as to see the difference between the real and the fake, the knowledge of what being neither Chinese nor bokgwai means.' $(1994,93)$

In Chin's aesthetics a strong modernist conception of the artist's singularity coexists with a profound sense of art's ethical responsibility. This is translated in the novel when Ulysses and his friends respond:

The Horse made us feel special. Unlike anyone else in the world, we were neither Chinese nor American. All things were possible. No guilt. We were pure selfinvention, something like Milton's Satan in Paradise Lost. 'self-begat.' (1994, 95).

Lest this theory of self-invention, eloquently invoked also at the beginning of The Chickencoop Chinaman, induce us to ascribe to Chin an ethnic refurbishing of neoPlatonic individualism with a touch of Emersonian pragmatism, I want to stress the circumstantial density that limits the affirmation of freedom or independent agency that Chin's characters embody in their comic resilience and vitality. I don't see any warrant here for 
egotism or a metaphysics of the Flaubertian artist-deity. The discourse of Gunga Din Highway can only lend itself to a fullblown nihilistic interpretation if the weight of history and the sociopolitical determinants that afford "objective correlatives" or, in Raymond Williams' (1977) term, "structures of feeling," are wilfully ignored.

\section{Discourse of Displacements}

Judging from the meager reviews of Gunga Din Highway, this historicising aspect of Chin's fiction has been neglected in favor of its colorful rhetoric and somewhat exhibitionist idiosyncracies. For example the New York Times reviewer focuses on Chin's fascination with Hollywood stereotypes and the penchant of superimposing on life a cinematic pattern that makes "The Movie About Me" the foil to the real world. The "Me," however, is a defensive mimicry of the prevailing individualist liberal ethos. Public anxiety with Chin's alleged humorous if "deadly cynicism" and canny ironic tone that distance the characters from the reader may indicate a certain resistance to the critique of media and mass culture in the novel, a critique that the publishing industry would be loathe to endorse. Another reviewer calls attention to the

frenetic, irreverent and episodic father-and-son saga that encompasses some five decades of American cliches, moviemaking and image bashing.... Chin sets Ulysses' serendipitous adventures within a comic book-style cultural survey that mocks everything American, from movies to music, drugs, politics, the media, pornography, and racism" (Seaman 1994, 111).

One reviewer, Robert Murray Davis, speculates that the reader is expected to have seen every movie from $M$ to Wild in the Streets and Night of the Living Dead, as well as some invented ones like Charlie Chan in Winnemucca and Ana May Wong to get a full appreciation of Chin's demystification of their aura. But the reference to these numerous artifacts of mass culture need not detract from the writer's purpose of carrying out a general demystification of appearances, especially when such appearances provide pleasure and catharsis that prevent the acquisition of knowledge required for unmasking the rationality 
of what is considered normal, natural, and reasonable.

Chin's cognitive mapping of the racial polity has often been downplayed if not ignored. His programmatic satire aims to interrogate the ideology of reification, in particular the reification of ethnicized gender and sexual practices. In the third section, "The Underworld," Chin recounts an incident he reported in the aforementioned interview with Studs Terkel. This deals with the time when he was challenged by the Chinatown Red Guards as he led his students reciting "Ching Chong Chinaman...." Ulysses explains the rationale: "Satire is where you make fun of how they think and what they say in order to make them look stupid" (1994, 257). This satiric motivation acquires a Rabelaisian accent in the summary of Benedict Mo's Fu Manchu Plays Flamenco; the play, according to Ulysses, aims to create not a hybrid artifact symbolically overcoming exclusion and antimiscegenation laws, but "a ChineseAmerican culture that kicks white racism in the balls with a shiteating grin" $(1994,261)$. The play functions as the antithesis to the Charlie Chan archetype. But what is the play really about? Here is a partial summary. Fu Manchu tells the white captive to give up the secret to Kool-Aid or he will let his beautiful nympho daughter give him the dreaded torture of a thousand excruciating fucks and exotic sucks. But the white man defends the secret to Kool-Aid, and Fu's luscious daughter wheels the captive off to her silk-sheeted torture chamber. When the director sees Ulysses offstage watching, still in character, he tries putting Fu Manchu back onstage, reciting the classical Japanese haikus of Issa and Basho, breathlessly watching his daughter torture the white man by seduction. Then Ulysses gets the idea to have Fu play the guitar in rhythm to his daughter's hips while badmouthing the white captive's sexual organs, skills, and style in Spanish, English, and three dialects of Chinese:

So who knows and who cares whose idea it is for $\mathrm{Fu}$ Manchu to end his flamenco in the torture chamber by ripping open his robe and showing his body in a bra, panties, garter belt, and black net stockings, licking his lips as he makes a move on the white man, while Fu's daughter straps on an eight-inch dildo? The captive American screams the secret formula, not only for Kool-Aid but for Bisquick and Crisco, too $(1994,258)$. 
Commodity-fetishism linked to racialized sexuality is thematized here. The critic Sau-Ling Wong has commented on the preoccupation of American-born Chinese writers with the effects of the gendering of ethnicity-the reflex of effeminizing the Asian men and ultrafeminizing Asian women-while recent immigrant writers are more concerned with the ethnicizing of gender. The quotation above shows Chin's hyperbolic displacement of the stereotypes by the manipulation of a sign system immanent in commodity aesthetics (Haug 1986).

Chin's strategy of deploying various perspectives-not only Ulysses but also his sworn blood brothers Diego Chang and Benedict Mo-is designed to counter any single narrative authority, even though his voice with its mocking insinuations and insouciance seems to predominate. Ego-building is not the agenda but the collective response to white racist practices. It may be noted here also that Chin's carnivalesque repertoire of deflation linked to the revolutionary social impulse of comedy effectively counters any psychologizing of racism and liberal ideology. The satiric and comic framework neutralizes the psychoanalytic obsession over the enigma formulated by Suzanne Yang (1998): "What is the opposite of an Asian woman?"

We confront again the problematic of Orientalism signaled at the outset-the objectification of the exoticized Other-that inheres in the valorization of difference as such. Yang analyzes the enigma of racist love as the "scopic constitution of racial identity mediated through an imaginary representation of the desire of the Other" $(1998,140)$. This Lacanian formula of ethnicity as a syndrome of ignorance, love, and hatred coalesced together, leads to an answer to the question of representation: the remainder (of what?) imagined as lost in the Other produces an aporia, which is the terrain of curiosity, desire, racism. It is this aporia that Gunga Din Highway exposes as an illusion generated by the contradictions in real life. Racial categorizing, the chief symptom of lived contradictions, results from the spontaneous reproduction of bourgeois social relations mediated by money, commercial transactions, and the pervasiveness of commodity fetishism in media and all cultural practices. In the everyday interaction of stratified groups in a racialized milieu, the legitimacy of the system can thrive on the continued reproduction of differences normalized in a system of depend- 


\section{Ethnic Studies Review Volume 24}

ency: the Other lacks what I (the white master) as owner of the means of production/reproduction have. And, what is more decisive, I know it. In short, the role of the actor Charlie Chan, born from this system of dependency and representation, can never be played by a Chinese, nor by any non-Western performer. The code of Othering prevails.

The conclusion of the novel returns us to George Stevens' film Gunga Din, after whom this highway of re-negotiation of "subject-positions," as the fashionable idiom has it, is named. Ulysses confidently asserts that "this is not The Movie About Me," his father is patently absent in it. It is "nothing but the real old movie." Aside from indexing the circumstantial conjunctures of the individual episodes, variants of a talk-story addressed to a select audience (mainly aficionados of Asian American literature), the Hollywood productions referenced throughout exemplify the ideological apparatus of racialization which, once internalized, produce symptoms of the Gunga Din complex. But what I want to call attention to is not this accumulation of period references and artifacts that gives us a sense of how the racial subordination of the Chinese and other Asians has been maintained. Rather I want to stress that it is from the subtle undercutting of the postmodernist styles of pastiche, collage, discordant rhetorical registers, and so on, counterpointed to a narrative scaffolding derived from Chinese and Western mythology and modernist artistic practices, that Chin fabricates this peculiar form of literary "installation" meant to dereify the alienation of social relations in the racial polity. Heterogeneity of novelistic form is thus meant to lay bare, expose, or defamiliarize the real contradictions taken for granted in the bureaucratic routine of everyday life (Lefebvre 1971).

For Chin, the project of dereification began in the sixties, notably with the plays The Chickencoop Chinaman and The Year of the Dragon: cliches, stereotypes, and the doxa of white supremacy were dismantled by techniques of allegory, reverse ventriloquism, theatrical distancing, and so on. From the somewhat mannerist, self-conscious Faulknerian rhetoric of "The Chinatown Kid" and other stories in his collection The Chinaman Pacific and Frisco R.R. Co., Chin switches to the flat reportorial idiom of Donald Duk in which the whole saga of thousands of Chinese workers building the transPacific railroad 
is refunctioned to serve as an organon for sustaining a communal ethos in Chinatown (indigenized ghetto/reservation and locus of pacification) through the shared dreams of parents and children. Chin repeats his injunction via the Father's declaration to his son: "History is war, not sport!.... You gotta keep the history yourself or lose it forever, boy. That's the mandate of heaven." A sense of long duration in historiography is evoked at the end of Donald Duk as the 108 toy airplanes explode in flight:

....and Donald Duk remembers dreams, the 108 horsemen galloping across the cloud over the ten miles of track just layed by the 1,200 Chinese and eight Irishmen. And very quickly they are all gone. Not a sound. Not a flash. All 108 stick-and-paper model airplanes gone. "Anybody hungry?" Dad asks.... Like everything else, it begins and ends with Kingdoms rise and fall. Nations come and go, and food. (1991, 173)

Food of course functions here as a marker of an oppositional cultural politics, as in much Asian American fiction (Waller), but surely this whole culinary knowledge/praxis cannot be dissociated from the nexus of gender, sexuality, class, and other patterns of socialization. The transitory, cyclical, and the permanent coexist in the mythmaking impulse of the novelist, but what endures is the totality of history in which the Chinese in America, stratified by class, gender, and sexuality, continue as a racialized collectivity participating in a struggle for hegemony and social transformation. Binationality, or the dilemma sketched by Wang that I outlined earlier, cannot predetermine the limits of this community's power to intervene in the ongoing process of class/race antagonism.

Ultimately, Chin's strategy of calculating social relations harbors a profound utopian motivation. His vision of the place of the Chinese in a foreshadowed egalitarian American society inheres in transfiguring the idea of process-in this case, the topos of the road/physical route institutionalized by Jack Kerouac, Robert Frost, Robert Penn Warren, Paul Bowles, and others-into a matter of geopolitical strategizing (life/history is articulated as the perpetual antagonism of forces). What is at stake is not a heroic masculinist dispensation but the recogni- 


\section{Ethnic Studies Review Volume 24}

tion of Chinese creativity and the communal virtues of discipline and cooperation. In the essay "Rashomon Road: On the Tao to San Diego" (circa 1995), Chin continues his attack on Betty Lee Sung and others who preach from "the pulpit of acceptance, absorption, and assimilation," who persist in "ornamenting white fantasy" and denying the place of the Chinese as producers and contributors to an evolving American civilization. In a gesture of "militant particularism" (Harvey 1996), Chin inscribes Chinese American history in the recursive texts/memory of concrete locales and sites, hyphenating ethnicities in the geopolitical arena:

The history of the Chinese in California is written in miles of old mining roads, and the railroad.... The road was going to be an adventure with father and son discovering the deserts, valleys, mountains, volcanoes, birds, cities, friends.... Asian American writers born and raised in America without feeling split between two incompatible cultures... the Asian American identity crisis didn't exist for us. We knew Chinese or Japanese culture and knew white American culture, and knew we were not both, nor were we the best of the East and the best of the West. We knew we were neither. Being neither did not mean we contemptuously ridiculed and stereotyped every culture we were not.... For us, the adventure in Asian American writing was not just in the writing but in the study, the discovery, the history... (1997, 290).

The artist then is not only an individual pioneer charting new territory but also, to paraphrase James Joyce (1964), the artificer forging in his imagination the "uncreated conscience" of his "race."

\section{Untimely Intervention}

In an ongoing research project, I inquire into Chin's allegorical-didactic remapping of the U.S. racial formation, its uneven-and-combined development, to ascertain the "weak link" where popular-democratic forces can attack. For the moment, I want to conclude by commenting on Chin's intervention in an event that reveals an anarcho-libertarian impulse underlying his populist posture. In October, 2000, Prof. Murray 
Davis, president of the Western Literature Association, recommended to his organization that Chin be given the Distinguished Lifetime Achievement Award for its annual 2000 meeting. Davis' colleagues objected on various grounds: Chin was abrasive, a misogynist and also a homophobe: in short he was unacceptable. Davis threatened to resign; eventually, a compromise was reached and Chin was invited to speak/read at the 2000 WLA Conference.

Chin demurred. Informed about the entire situation, Chin wrote Russell Leong, editor of Amerasia Journal, and dismissed the event as a "kangaroo court." Chin compared the proceeding to the way the Asian American Studies Association treated Lois Ann Yamanaka when the Filipinos objected to her receiving a prize from the Association. Chin concluded that without considering the literary merits of Yamanaka's novel, "Yamanaka became the asteroid that killed the dinosaurs." Filipinos as dinosaurs? A Hawaaian Japanese as an asteroid? Having warmed up by denouncing the Filipino Caucus as a bunch of ignoramuses, Chin launched into a tirade against specific and vaguely generalized enemies, the specific ones being those "feminists" on the executive board of the Association who "had heard about my rotten personality, not anything of mine they'd read...." He went on with righteous indignation:

I wonder how many Asian American writers have heard of the Western Literature Association? I wonder how many will mount up their mighty superior minds and demand they give me the association lifetime achievement award? No, I don't. And there's no need to wonder at how many Asian American writers will write the association saying, they have no business telling the Association what to do with its lifetime achievement award, except never to stick them with it. There's only one like that. And l'm it. And they're not giving me their award. They're giving me a kangaroo court instead. And the incoming president of the association is mad. The association magazine won't publish his account and protest of what happened in Sacramento. Perhaps you will (Leong 2000).

The artist's autonomy becomes an emblematic stand-in for the right of a nationality to self-determination, except that in con- 


\section{Ethnic Studies Review Volume 24}

flating the Filipino protest against Yamanaka's aestheticist insensitivity and the prejudices of the Western Literature Association's officers, Chin succumbs to the artisanal code of ethics reminiscent of the feudal warriors in his beloved canonical Chinese texts. This is where Chin's sensibility becomes a counter-productive instrument in the field of commodifying knowledge/power.

\section{Mediations}

Writing and living, for Chin, are matters of strategy concerned with relations, transitions, and passages from one position to another. Strategy is involved with establishing connections, linkages, and modalities of change from one situation to another. Structured between cultures/histories-China/America, the Chinese American artist confronts the additional predicament of mediating differences brought about by the whole racialized history of the United States: conquest and genocide of the American Indians, slavery and segregation of African Americans, colonization of Mexicans, Puerto Ricans, Filipinos, Hawaiians, and now the wholesale stigmatization of citizens of Arab or Middle Eastern descent. Asians as a "buffer race," the "model minority" disengaged from the State apparatus of institutional racism-this condition is one way in which subaltern alterity or the in-between predicament I sketched at the beginning is resolved. Ironically this reformist turn reproduces the lower classes of the group as inassimilable or permanent aliens (San Juan 1999).

Modalities of resistance cannot substitute for the ultimate overthrow of the racial system. In "Back Talk" Chin urged that the strategy of resistance must replace the psychology of laying low, the habitual exercise of "forestalling the Great Deportation" for those who have accepted the status of sojourners (557). Lacking "an articulated, organic sense of our identity" and plagued by a suicidal "dual personality" produced by America's racist love, Asians need to reflect on their history, on their shifting geopolitical positions and locations in the American landscape. Although Chin insists that Asian culture is martial and migratory, not migrant, he is unable to escape the nexus of America as the road, depot, marketplace, and its tropological construction as a moving arena of class conflict for 
immigrants. By indigenizing this trope, Chin safeguards himself from being instrumentalized by a conservative cultural nationalism such as that of Singapore, for example, which recuperated David Henry Hwang's M. Butterfly to serve reactionary authoritarian-capitalist ends (Lye 1995).

What about the formula of postcolonial hybridity, syncretism, and opportunistic ambiguity? Given this materialization of U.S. history for Chin, American culture is not a fixed but a pidgin or bastard culture; like the language it is "a pidgin marketplace culture" $(1997,295)$. Anything has value so long as it can be exchanged (the sensuous particulars reduced to quantitative abstraction), so long as it enters into market circulation. If this is so, then what awaits the new immigrants from Taiwan, Hong Kong, and China who conceive of the United States not as a temporary place to work but as a new home with flexible economic opportunities (Takaki 1989)? Why are these new immigrants still perceived as the perpetual foreigners, countless potential Vincent Chins indistinguishable from the aggressive "oriental" competitor, the Japanese (Chasin 1998)? In fact, we now have a situation where the new rich Chinese immigrants from Hong Kong, whom Aihwa Ong calls "transnational cosmopolitans," have rearticulated the resonance of extraterritorial domination with their familial biopolitics and parachute kids, a force strong enough to supposedly challenge the "American class ethos of moral liberalism" $(1999,284)$. In this context, Gordon Chang (1999) has suggested that the transnational approach exemplified by the scholarship of Ong, Dirlik and others may break away from the old method of "a nationally based historicism" which circumscribed the diaspora and social-history approaches. But I think this needs to be qualified, given the tendency of transnationalism as well as postcolonialist discourse to erase the stark unequal power-relations among nation-states, nationalities, regions and therefore legitimize the oppressive, iniquitous status quo (San Juan 2002).

We can rehearse the questions that Chin has tried to narrativize with more theoretical engagement. Is racist love now eliminated by this new phenomenon of performative, not normative or even "accidental" Asians: "cultural citizenship as subjectification and cultural performance" (Ong 286)? Or are those now gifted with exorbitant symbolic capital still compelled to 


\section{Ethnic Studies Review Volume 24}

traverse Gunga Din Highway filled with supermalls, reproducing an exchangeable use-value (a quintessential Chineseness, whatever that is) in the service of global capitalism on the warpath against terrorist Others? These are questions that Chin has attempted to answer and that Chinese as well as other Asian writers will have to respond to in the next millenium for the sake of much more worthy ideals.

\section{References}

Bakhtin, Mikhail. 1981. The Dialogic Imagination. Austin: $U$ of Texas Press.

Bourdieu, Pierre. 1996. The Rules of Art. Tr. Susan Emanuel. Stanford: Stanford University Press.

Chan, Sucheng. 1991. Asian Americans: An Interpretive History. Boston: Twayne Publishers.

Chang, Gordon. 1999. "Writing the History of Chinese Immigrants to America." The South Atlantic Quarterly 98.1/2 (Winter/Spring): 13542.

Chasin, Barbara. 1998. Inequality and Violence in the U.S. Amherst, NY: Humanity Books.

Chavez, Linda. 1998. "Civic Education in a Changing Society." Multiculturalism and American Democracy. Ed. Arthur Melzer et al. Lawrence: $U$ of Kansas Press.

Cheung, King-kok. 1990. "The Woman Warrior versus the Chinaman Pacific: Must a Chinese-American Critic Choose Between Feminism and Heroism?" Conflicts in Feminism. Ed. Marianne Hirsch and Evelyn Fox Keller. New York: Routledge. 240-246.

Chin, Frank. 1976. "Back Talk." Counterpoint: Perspectives on Asian America. Ed. Emma Gee. Los Angeles: Asian American Studies Center.

—. 1983. "Our Life is War." Seattle Weekly, May 4: 28-32, 34-38. 
San Juan-Gunga Din Highway

—. 1988. The Chinaman Pacific and Frisco R.R. Co. Minneapolis: Coffee House Press.

—_ 1991. Donald Duk. Minneapolis: Coffee House Press.

—. 1992. "Interview." Race by Studs Terkel. New York: The New Press. 309-313.

—. 1994. Gunga Din Highway. Minneapolis: Coffee House Press.

-1 1997. "Rashomon Road: On the Tao to San Diego." MultiAmerica: Essays on Cultural Wars and Cultural Peace. New York: Penguin Books.

Davis, Robert Murray. 1995. "Gunga Din Highway." World Literature Today 69 (Spring): 360-361.

Dirlik, Arif. 2001. "Literature/Identity: Transnationalism, Narrative and Representation." Lecture delivered at the University of Michigan, Ann Arbor, November 1.

Goldmann, Lucien. 1975. Towards a Sociology of the Novel. London: Tavistock Publications.

Gotanda, Neil. 1996. "Multiculturalism and Racial Stratification." Mapping Multiculturalism. Ed. Avery Gorden and Christopher Newfield. New York: Routledge.

Gran, Peter. 1996. "Beyond Eurocentrism: A New View of Modern World History." Syracuse: Syracause University Press.

Harvey, David. 1996. Justice, Nature and the Geography of Difference. Malden, Mass: Blackwell.

Haug, W.F. 1986. Critique of Commodity Aesthetics. Minneapolis: U of Minnesota Press.

Hongo, Garrett. 1998. "Culture Wars in Asian America." The Social Construction of Race and Ethnicity in the United States. Ed. Joan 


\section{Ethnic Studies Review Volume 24}

Ferrante and Prince Brown, Jr. New York: Longman. 51-55.

Jameson, Fredric. 1998. Brecht and Method. London: Verso.

Joyce, James. 1964 (1916). A Portrait of the Artist as a Young Man. Ed. Chester Anderson. New York: The Viking Press.

Lefebvre, Henri. 1971. Everyday Life in the Modern World. New York: Harper Torchbooks.

Leiwei Li, David. 1991. "The Formation of Frank Chin and Formations of Chinese American Literature." Asian Americans: Comparative and Global Perspectives. Pullman, WA: Washington State University Press. 211-224.

Leong, Russell. 2000. Personal communication to the author via email (December 10).

Lukacs, Georg. 1971 (1968). History and Class Consciousness. Tr. Rodney Livingstone. London: Merlin Press.

Lye, Colleen. 1995. "M. Butterfly and the Rhetoric of Antiessentialism: Minority Discourse in an International Frame." The Ethnic Canon. Ed. David Palumbo-Liu. Minneapolis: University of Minnesota Press.

Mills, Charles. 1997. The Racial Contract. Ithaca, NY: Cornell University Press.

Needham, Joseph. 1975. "History and Human Values: A Chinese Perspective For World Science and Technology." Lecture given to the Canadian Association of Asian Studies Annual Conference. Montreal, May. Typescript, 37 pages.

Omatsu, Glenn. 1994. 'The 'Four Prisons' and the Movements of Liberation: Asian American Activism from the 1960s to the 1990s." The State of Asian America. Ed. Karin Aguilar San Juan. Boston: South End Press. 19-70. 
Ong, Ainwa. 1999. "Cultural Citizenship as Subject Making." In Race, Identity and Citizenship: A Reader. Ed. Rodolfo Torres, Louis Miron, and Jonathan Xavier Inda. Oxford: Blackwell.

Palumbo-Liu, David. 1999. Asian / American. Stanford: Stanford University Press.

Ricci, Claudia. "Gunga Din Highway." New York Times Book Review 29 January 1995: 16.

Seaman, Donna. 1994. "Gunga Din Highway." Booklist 15 September: 111.

Said, Edward. 1978. Orientalism. New York: Random House.

San Juan, E. 1998. Beyond Postcolonial Theory. New York: St Martins Press.

-1999. "From the Immigrant Paradigm to Transformative Critique: Asians in the Late Capitalist United States." Race, Ethnicity, and Nationality in the United States. Ed. Paul Wong. Boulder: Westview Press. 34-54.

- 2002. Racism and Cultural Studies. Durham, NC: Duke University Press.

Steadman, John. 1969. The Myth of Asia. New York: Simon and Schuster.

Takaki, Ronald. 1989. Strangers from a Different Shore. Boston: Little, Brown and Co.

Terkel, Studs. 1992. Race. New York: The New Press.

Waller, Nicole. 1995. "Past and Repast: Food as Historiography in Fae Myenne Ng's Bone and Frank Chin's Donald Duk." Amerikastudien 40.3: 485-502.

Wang, L. Ling-chi. 1995. "The Structure of Dual Domination: Toward 
Ethnic Studies Review Volume 24

a Paradigm for the Study of the Chinese Diaspora in the United States." Amerasia Journal 21: 1 \&2: 149-169.

Williams, Raymond. 1977. Marxism and Literature. New York: Oxford University Press.

Wong, Sau-ling Cynthia. 1992. "Ethnicizing Gender: An Exploration of Sexuality as Sign in Chinese Immigrant Literature." Reading the Literature of Asian America. Philadelphia: Temple University Press.

Yang, Suzanne. 1998. "A Question of Accent: Ethnicity and Transference." The Psychoanalysis of Race. Ed. Christopher Lane. New York: Columbia University Press. 